\title{
Identification of Andesite Resource Potential In Kalirejo Area, Kokap Sub-District, Kulon Progo Using Resistivity Method
}

\author{
Rizqi Prastowo ${ }^{1,}{ }^{*}$, Hurien Helmi ${ }^{2}$, Obrin Trianda ${ }^{2}$, Rofiqul Umam ${ }^{3}$ \\ ${ }^{1}$ Mining Engineering, Institut Teknologi Nasional Yogyakarta, Jl.Babarsari, Caturtunggal, 55281, \\ Yogyakarta, Indonesia \\ ${ }^{2}$ Geology Engineering, Institut Teknologi Nasional Yogyakarta, Jl.Babarsari, Caturtunggal, 55281, \\ Yogyakarta, Indonesia \\ ${ }^{3}$ School of Science and Technology, Kwansei Gakuin University, Sanda-Shi, Hyogo-Ken, Japan \\ ") Corresponding Author: rizqi@itny.ac.id)
}

Received: 26 January 2021 / Accepted: 02 July 2021 / Published: 24 August 2021

\begin{abstract}
In the last five years, the need for materials to build infrastructure in Kulon Progo Regency has increased with the construction of an international airport. In the construction process, strong earth or rock materials are needed to make buildings resistant to earthquakes, one of which is andesite rock. This study aims to determine andesite rocks' resources using a three-dimensional model based on the value of resistivity in Kalirejo district Kokap Kulon Progo. The research was conducted by geological and geophysical survey. Based on data on the distribution of rocks in the research area included in the intermediate igneous rocks, andesite. These rocks are intrusions that develop in research areas. Petrography analysis is used to determine the types of minerals in andesite rocks and determine which levels of rock changes have changed or not to affect the strength of rocks. These rocks are intrusions that develop in research areas. Geophysical survey is by resistivity method using configuration dipole-dipole with five lines, and each stretch is $200 \mathrm{~m}$. Based on three-dimensional model resistivity, fresh andesite is at a depth of between $5-10 \mathrm{~m}$. Value of andesite resistivity is more than $668 \Omega \mathrm{m}$, while the value of weathered andesite resistivity ranges from $256-536 \Omega \mathrm{m}$ and andesite resources about 332,580 tons.
\end{abstract}

Keywords: Andesite, Geoelectric, Kalirejo, Resources

\section{Introduction}

In the Long-Term Development Plan of Kulon Progo Regency in 20052025, competitive and growing economic competitiveness makes the economy's structure more advanced and reliable. Sectors that support the economy are industrial, tourism, agriculture, marine, natural resources, and services. One that supports this is the business and investment in Kulon Progo equivalent to other developed areas (Pemerintah Kabupaten Kulon Progo, 2007). Until 2020, Kulon Progo Regency has had an investment in airports located in Temon District. To support the integration of Airport facilities, The Kulon Progo Regency government needs other facilities. Based on this, it is necessary to have material availability information to support the implementation of development. One of the critical materials is andesite. Andesite is a type of volcanic igneous rock used in construction such as building foundation raw materials, paving, and bridge construction. Its utilization is needed andesite rocks that have not experienced weathering (fresh), while most of the andesite rocks exposed on the surface have experienced weathering with different levels. Andesite is also a suitable aggregate-making material (Black, 2009). Andesite aggregates provide good density and contribute to a low coefficient of heat may value on concrete (Mackechnie, 2004). Based on this, it is necessary to have 
information about the presence of andesite in the area around Kulon Progo. One of the sciences to know the existence of andesite is geophysics. Geophysics is a science that studies the earth based on the magnitude of physics (Kearey et al., 2002).

Rocks having superior physical properties, such as hardness, density, and water and weather resistance, can be utilized appropriately for infrastructure since they are resistant to damage. Andesite is one of the rocks with a solid physical characteristic (Sariisik et al., 2011). Due to its vast chemical content of silica (SiO2) 62.30 percent, it is one of the mined rocks with a vast potential for civilization since it can be utilized as the primary material of buildings, bridges, roads, trains, and other structures (Chalikakis et al., 2011). Andesite is found in andesite intrusive rock units in the research region, ranging from hypersthenic andesite to augite-hornblende andesite and trachyandesite (Rahardjo et al., 1995). Because these rocks can also be connected with lava flow igneous rock types, miners must know that not all intrusive rock units are intrusive rocks. Miners must understand the distinctions between intrusive and lava rocks, thick but not widely spread, and lava rocks are broad but thin. This difference leads to discrepancies in potential resource calculations (Purwasatriya, 2013).

Geophysical exploration is one of the first surveys that can be carried out. In the discipline of geosciences, geophysical exploration is one of the sciences. Geophysical exploration can help with geological mapping, possible mining sites, and disasterprone locations, among other things ( $\mathrm{Hu}$ et al., 2007). The Geoelectric method is one of the geophysical approaches used to calculate the potential area of building material or substance (Galletti et al., 2013). The geoelectric method is a geophysical technique that uses the electrical properties of rocks, namely rock resistivity. Rocks are generally poor/resistant conductors of electricity, although their qualities and compositions vary, resulting in a wide range of resistivity levels (Phillips,
2006). Geoelectrical techniques can be used to assess the exploitability of these deposits as an alternative to high-cost drilling programs (Lugo et al., 2008). The resistivity value is used to discriminate between different types of rocks. The Geoelectric Method's 3D modeling of rock resistivity is projected to provide an overview of the pattern of mountain rock distribution (Woodruff et al., 2015). Its rock resistivity measures the electrical inhibition of rock. The lower the current that can flow in a conductor, the higher the resistivity rating of the rock, and vice versa (Hrenovic et al., 2009). The non-invasive nature of this procedure and its inexpensive cost are both positives (Guinea, 2010).

\section{Research Method}

Field research activities were carried out in Kalirejo Village, Kokap District, Kulon Progo Regency, Yogyakarta. Performance of early-stage activities in secondary data in regional geological maps of Yogyakarta sheets and early geological surveys to determine geoelectric stretches' location. This research was done by mapping the surface and subsurface by describing and grouping rocks based on geology and rock resistivity. Based on the mapping results, there is a unit of rocks in the form of andesite. Research conducted with geological and geophysical surveys, the flow of research can be seen in Figure 1.

Geoelectric measurements have been carried out as many as five lines with the dipole-dipole array. The geoelectric line is $200 \mathrm{~m}$ by $1 \leq \mathrm{n} \leq 6$. Geoelectric measurement is in 3 vertical lines and two horizontal lines. Measurements are carried out using a tool called Naniuara NRD 300. While data processing using RES2DINV software and 3D Modeling software. Dipoledipole is the array in a geoelectric method that will produce good imaging vertically and laterally (Octova, 2017; Dentith, 2014). 3D modeling of rockresistivity with the Geoelectric Method is expected to provide an overview of andesite rock distribution patterns. Modeling is significant in exploring andesite rocks to assess the potential and resources of andesite 
rocks in research areas. Method tomography promising results in the determination of resistivity will continuously develop with excavation materials (Mostafaie, 2015). increased measurement depth and accuracy Because the resistivity of rocks varies, Telford (Yan, 2012). The resistivity method shows (1976) defines resistivity as follows in Table 1.

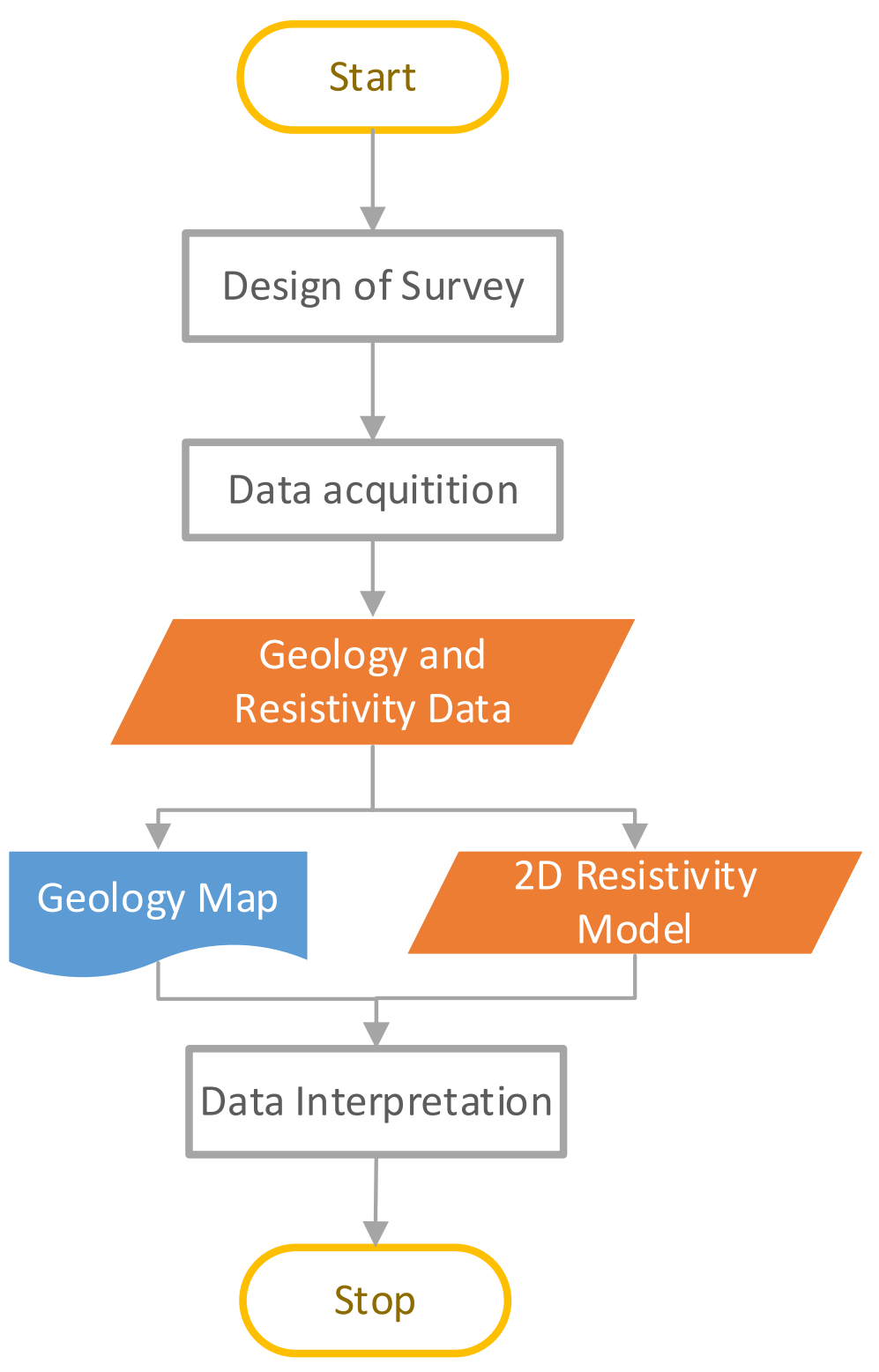

Figure 1. Flowchart of the research.

Table 1. Material Variations of the Earth (Rocks) (Guinea, 2010).

\begin{tabular}{cll}
\hline No & \multicolumn{1}{c}{ Name of rock } & Resistivity $(\mathbf{\Omega m})$ \\
\hline 1 & Air & 0 \\
2 & Clay & $1-100$ \\
3 & Ground Water & $0.5-300$ \\
4 & Old Breccia / Gravel & $100-600$ \\
5 & Old Andesite / Dry Gravel & $600-10.000$ \\
\hline \multicolumn{2}{l}{ The survey location map can be seen in Figure 2 below. }
\end{tabular}




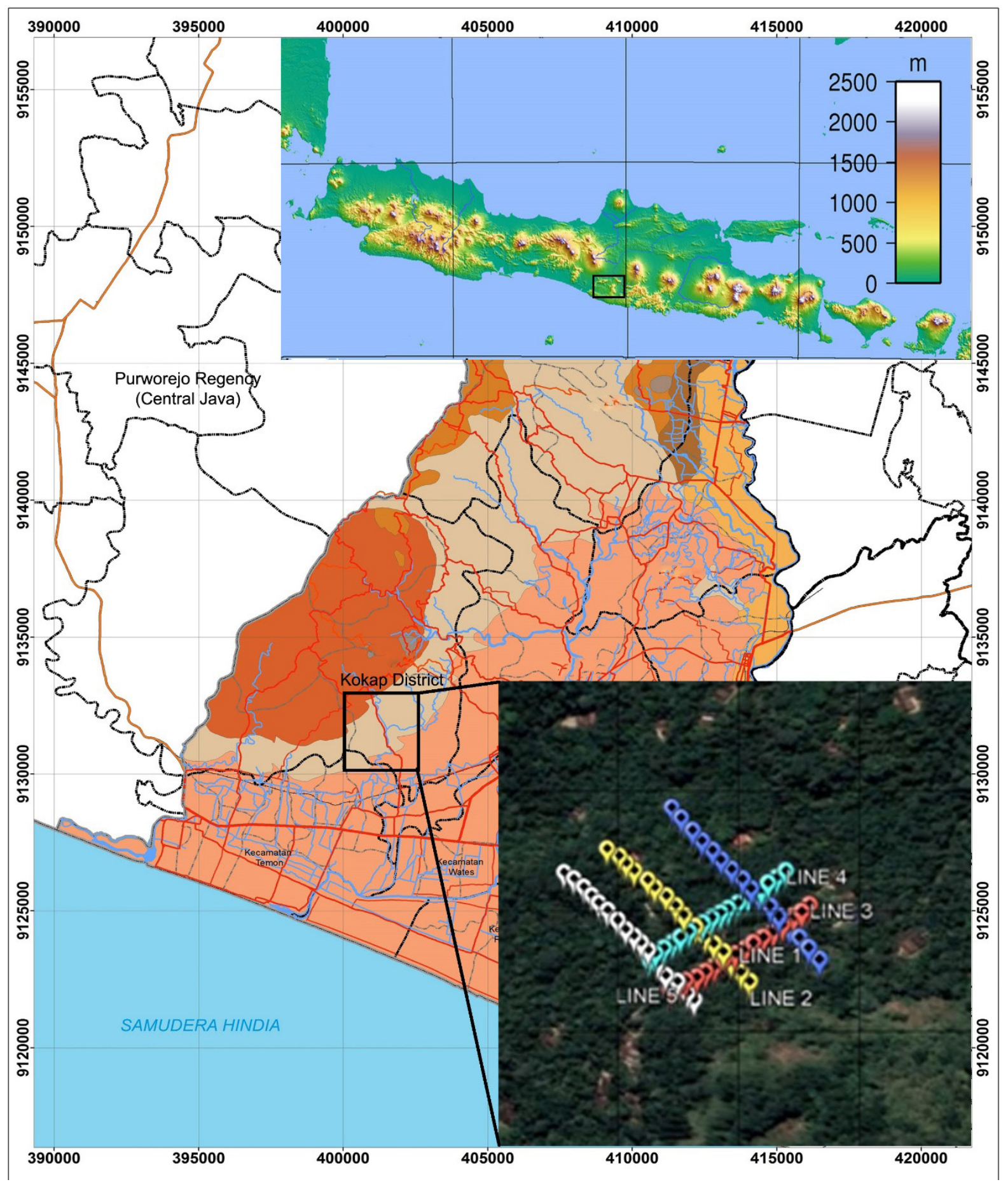

Figure 2. Survey location.

\section{Results and Discussion}

\subsection{Results}

The Kulon Progo Mountains are defined as large domes with flat peaks and steep slopes. The dome's core consists of three old andesite volcanoes, whose former magma chambers are now open (Harjanto, 2011). Elephant Mountain, located in the dome's center, is two of the oldest volcanoes that produce Hypersthenic Augite Andesite rock. Mount Ijo produces basaltic andesite pyroxene. Mount Menoreh was the youngest volcano to make andesite hornblende on Aug. Determination of 6 units of formations in the Kulon Progo Mountains from old to young, namely: Central-Oligoceous Nanggulan Formation, 
Kaligesing Formation, Dukuh Formation, Jonggrangan Central Miosen Formation, Central-Late Miosen Sentolo Formation, and Alluvium (Van Bemmelen, 2009). Kulon Progo Volcanokano stratigraphy Based on Analysis through topographic and morphological maps, satellite imagery, absolute age assessment data, and field observation, the stratigraphy of the research area consists of three hills (Ijo, Jonggrangan, and Sigabug) and two volcanic hills (Kukusan and Pence) (Harjanto, 2011). The geological observations show that the study area is dominated by andesites, as seen in Figure 3.

Inversion 2D modeling is done using the smoothness-constrained least square method that is the basis of the RES2DINV software algorithm. 2D modeling provides lateral variations of resistivity values but total resistivity values for horizontal directions (Hersir, 2013). The electrical properties of rocks are influenced by ionic concentration, surface conduction, fluid saturation, porosity, and pore connectivity (Oh et al., 2014). Inversion is a 2D cross-section resistivity model that provides information on the variation of resistivity value (prisoner type) below the measurement point. Based on the results of the inversion shown in Figure 4 obtained resistivity value response (electrical resistance) with a value of more than $779 \Omega \mathrm{m}$ is indicated by purple in the cross-section where there is andesite, the value of resistivity (electrical resistance) with a value of $300-400 \Omega \mathrm{m}$ is indicated by yellow to orange in the cross-section is weathered andesite.

Based on the results of the inversion shown in Figure 5 response data obtained resistivity value (electrical resistance) with a value of more than $1500 \Omega \mathrm{m}$ indicated by purple color on a cross-section of fresh Andesite resistivity value (electrical resistance) with a value of $400-600 \Omega \mathrm{m}$ indicated by yellow to orange on the weathered Andesite cross-section.

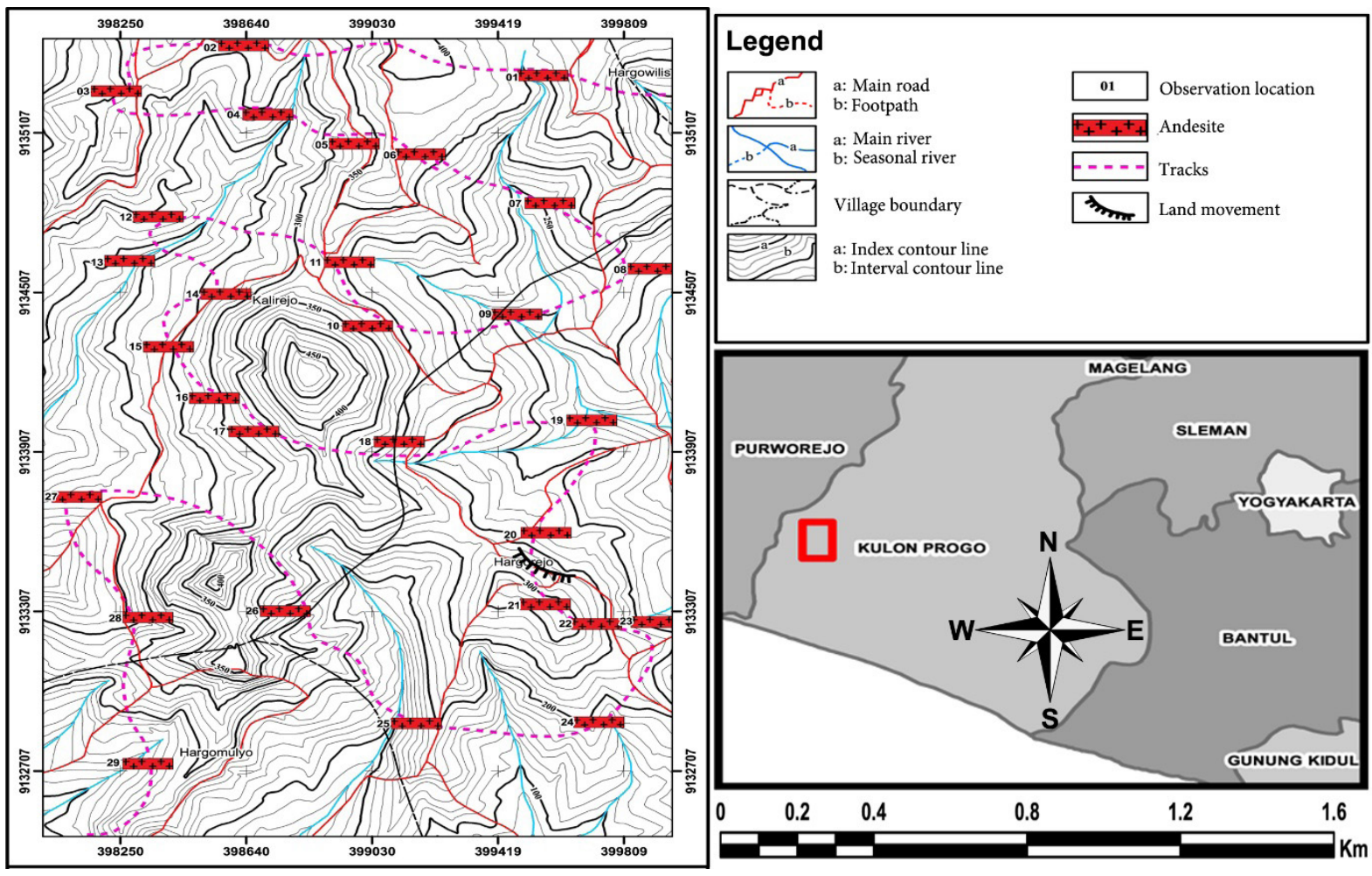

Figure 3. Local Geology Map. 


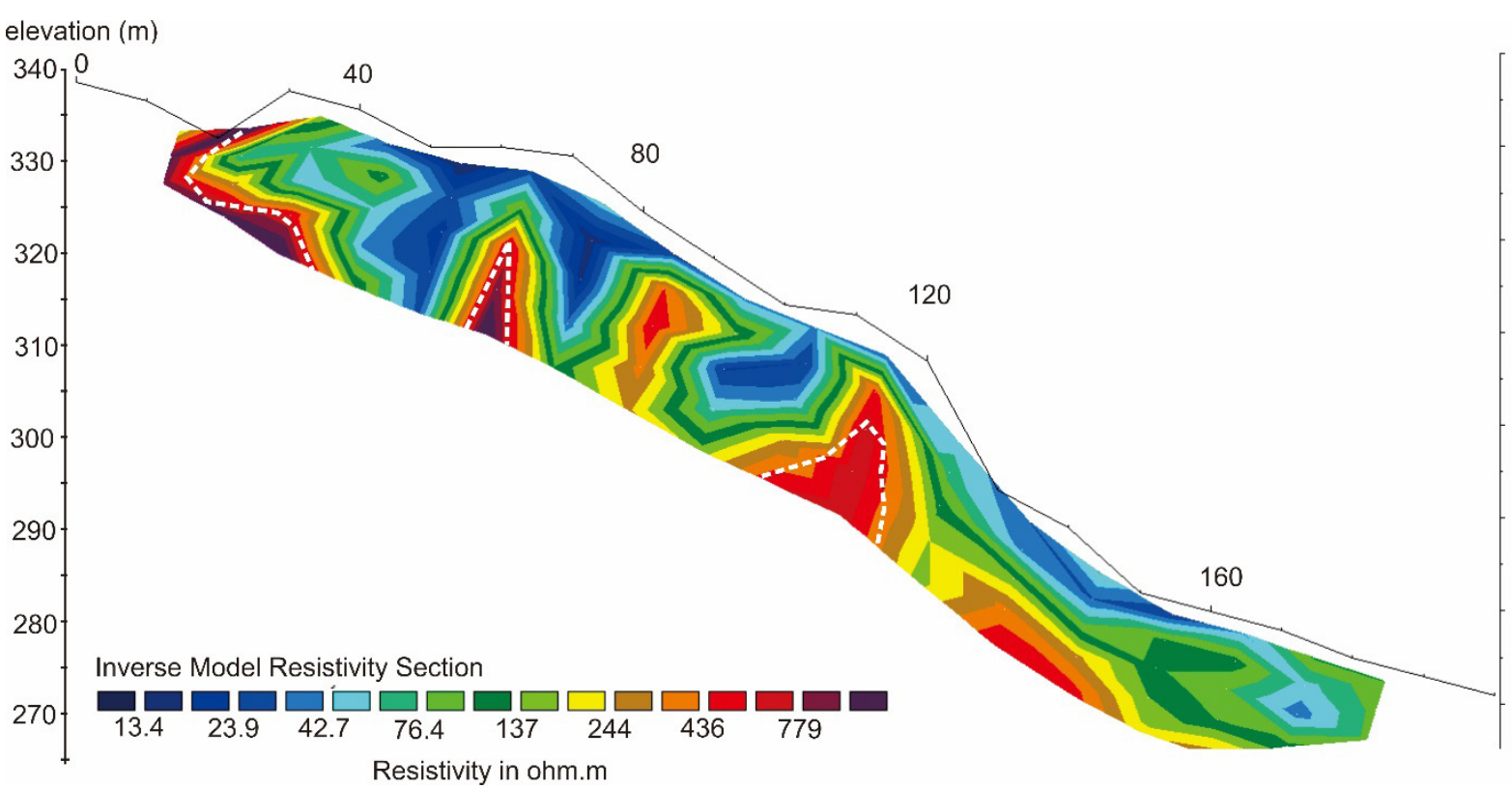

Figure 4. Resistivity Modeling Line Interpretation 1.

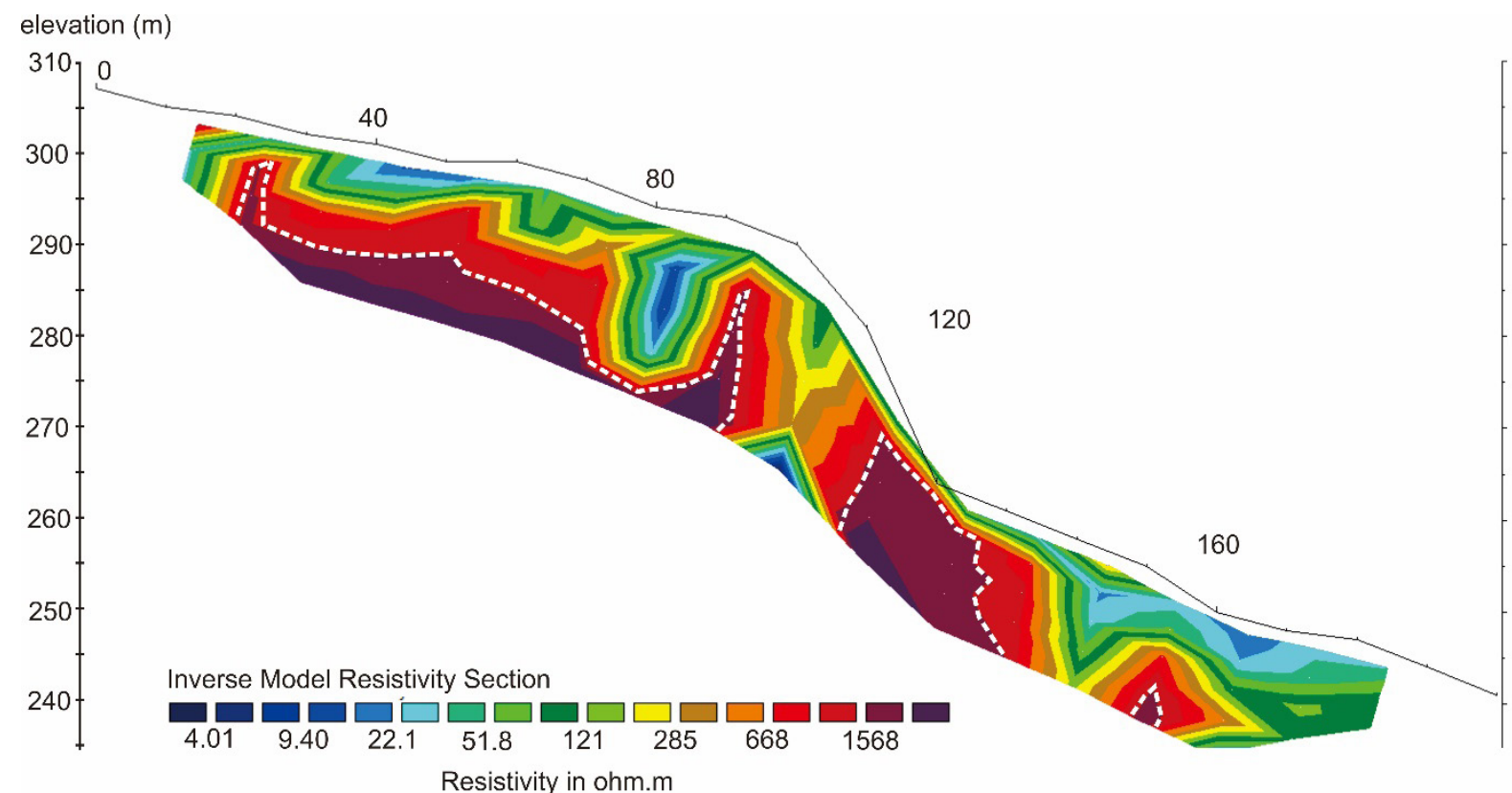

Figure 5. Resistivity Modeling Line Interpretation 5.

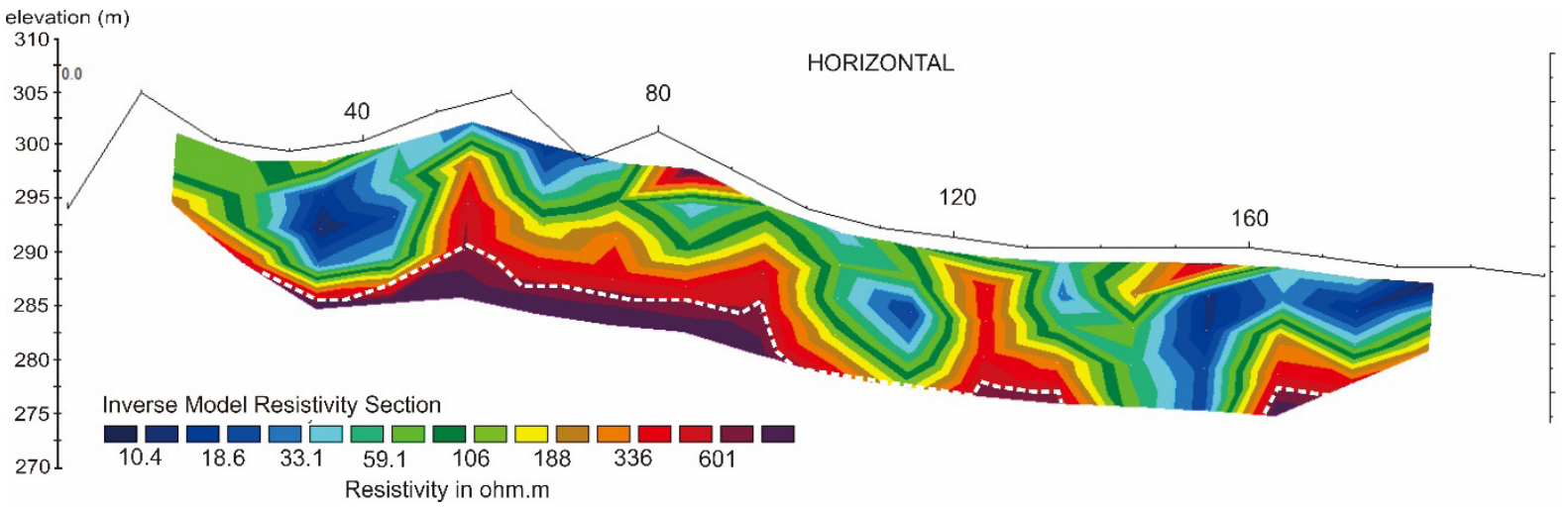

Figure 6. Resistivity Modeling Line Interpretation 4. 


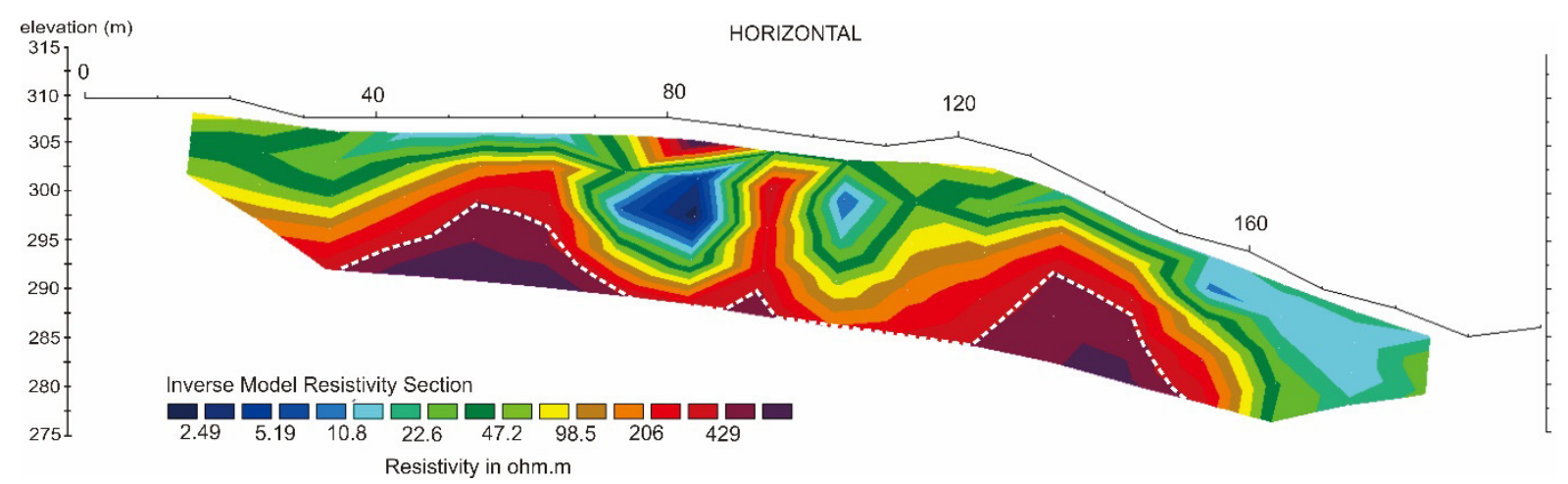

Figure 7. Resistivity Modeling Line Interpretation 3.

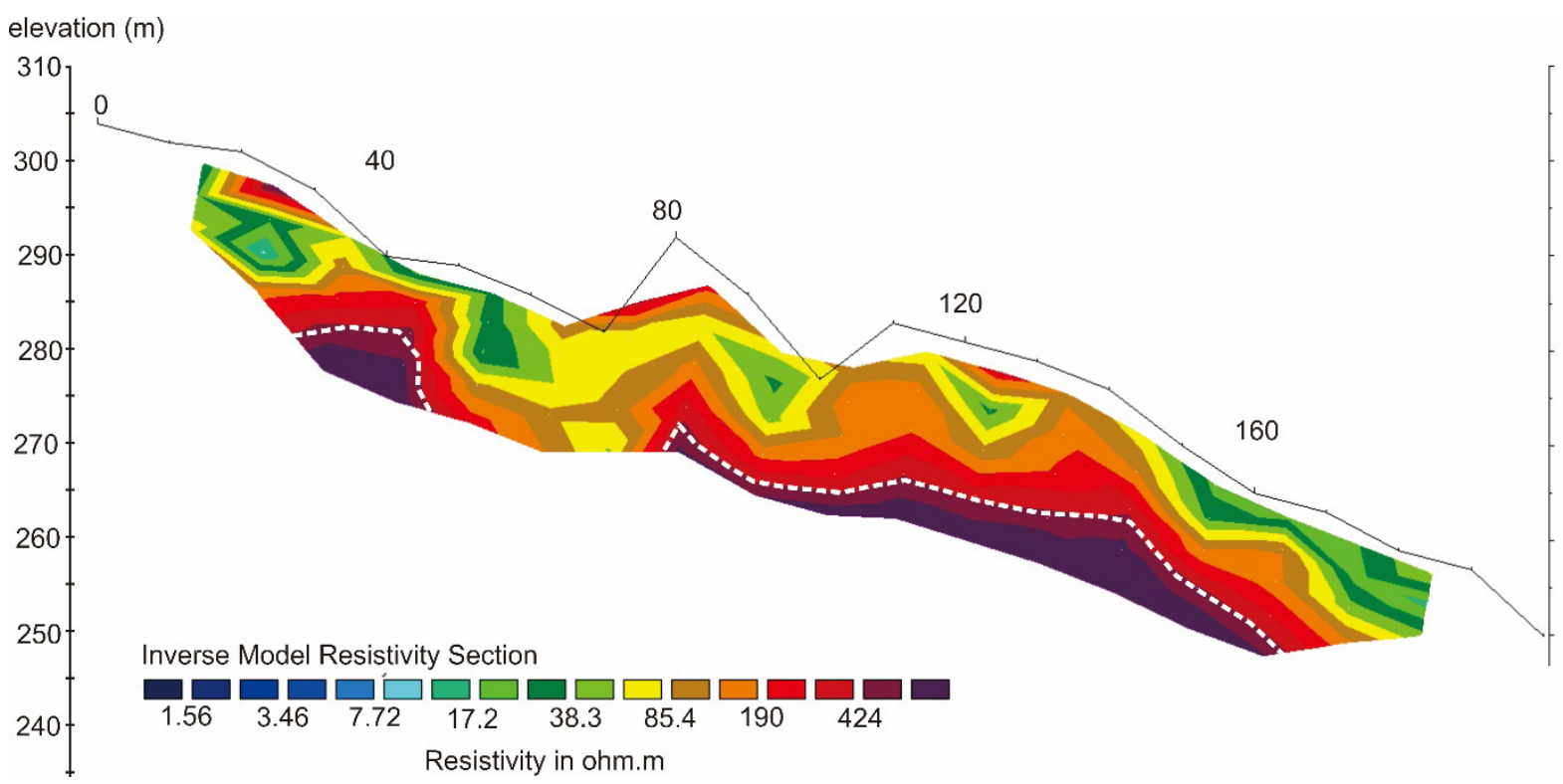

Figure 8. Resistivity Modeling Line Interpretation 2.

This 4th line is a horizontally pointed stretch. Based on the results of inversion shown in Figure 6 obtained the response of resistivity value (electrical resistance) with a value of more than $700 \Omega \mathrm{m}$ indicated by purple color on a cross-section that is fresh andesite, resistivity value (electrical resistance) with a value of 300 $400 \Omega \mathrm{m}$ is indicated by yellow to orange in the cross-section is weathered andesite.

Line 3 (Figure 7) is also a horizontally pointed stretch. Based on the inverse shown in Figure 6, the overall response obtained is andesite, where the resistivity value (electrical resistance) with a value of more than $500 \Omega \mathrm{m}$ is indicated in blue to purple. The breccia is visible from about $10 \mathrm{~m}$ and stretches for $100 \mathrm{~m}$, and there is still continuity.
Based on the inverse results shown in Figure 8 , the overall response obtained is andesite, where the resistivity value (electrical resistance) with a value of more than $500 \Omega \mathrm{m}$ is indicated in blue to purple. The andesite is visible from a depth of about $10 \mathrm{~m}$ and stretches for $80 \mathrm{~m}$.

\subsection{Discussion}

Based on data on the distribution of rocks in the research area included in the intermediate igneous rocks, andesite. These rocks are intrusions that develop in research areas. Petrography analysis is used to determine the types of minerals in andesite rocks and determine which levels of rock changes have changed or not to affect the strength of rocks. 
The petrography analysis of andesite rocks has a porphyritic texture. Fenokris with crystal size $>0.1 \mathrm{~mm}$ consists of plagioclase, pyroxene, hornblende.

Plagioclase is $56 \%$, on Plane Polarized Light (PPL) observation, minerals show colorless, euhedral-subhedral crystal shape, 1-way hemisphere, low relief. On Cross Polarized Light (XPL) observations of weak birefringence 0.009-0.011 first-order white interference color, extinction angle 260, Plagioclase dominated by An 48 labradorite, albeit twin, also Carlsbadalbeit found. The percentage of pyroxene is $11 \%$. On Plane Polarized Light (PPL) observations, minerals showed grey to brownish color, anhedral-subhedral crystal shape, high relief, 2-way hemispheres. On Cross Polarized Light (XPL) observations, birefringence is medium 0.037-0.040 second-order, parallel blackout angle. The percentage of hornblende is $8 \%$, on Plane Polarized Light (PPL) observations is greyish-brown, high relief indicates weak pleochroism. Medium-high replacement with the 2-way angled slit. On Cross Polarized Light (XPL) shows yellowish-brown color, medium relief, $\mathrm{n}>$ balsam, BF 0.033-0.059, parallel blackout, long-slow orientation (Prastowo et al., 2019). Based on petrographic analysis data, rocks in the research area, including AndesiteBasaltic type and seen from the geography of this rock, is very good without any effect of changes seen from the pore value of rocks are very small so that it can be used as building supporting materials (Sadjab et al., 2020).

Based on the geoelectric measurement of polished-polished configuration, obtained andesite 3D model as in Figure 9. Based on the andesite 3D model tends to spread to the southeast-northwest. The andesite volume of $144,600 \mathrm{~m}^{3}$. The distribution of andesite is seen in Figure 9 with light blue color, and the position of the data with a red dot is a data point of resistivity measurement. Andesite resources are obtained by multiplying the volume by the mass of the andesite type, which is 2.3 tons/ $\mathrm{m}^{3}$. A large amount of andesite resources in the research area is 332,580 tons. The result of another research showed Kokap area is dominated by Andesite rock; research was also conducted about the potential of andesite resources in the kokap area, using a geoelectric method (Purwasatriya, 2013; Giamboro \& Hidayat, 2016; Prastowo, 2017). Differences in measurement methods lead to differences in potential resource determination (Triani et al., 2021). This proves that the high area of Kokap area, Kulon Progo is dominated by andesite rocks. The rocks around Mount Ijo Kokap Kulon Progo are Andesite and Dasit, where dacite is considered to have intruded andesite in the central Miosen period (Irzon, 2018).

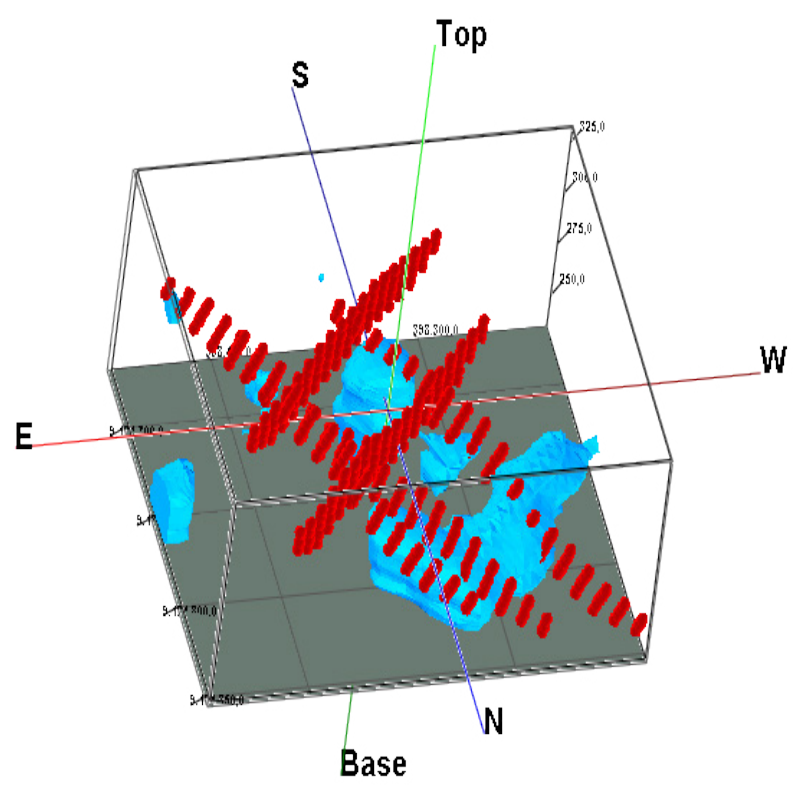

Figure 9. 3D Modelling Resistivity.

\section{Conclusion}

The working principle of the geoelectric method is done by injecting an electric current into the ground through a pair of electrodes and measuring the potential difference with another pair of electrodes. When an electric current is injected into a medium and the potential difference (voltage) is measured, the resistance value of the medium can be estimated. Based on geoelectric measurements of the dipoledipole configuration, a 3D model of ndesite tends to spread to the southeast-northwest with an andesite volume of $144,600 \mathrm{~m}^{3}$. Andesite resources are obtained by multiplying 
the volume by the density of ndesite, which is 2.3 tons $/ \mathrm{m}^{3}$. Distribution of andesite resistivity value $(>500 \mathrm{~m})$ through a cross-section of $3 \mathrm{D}$ resistivity models tends to spread flat under the measuring trajectory with a depth of about 1015 meters and a resource of about 332.580 tons. The results of other studies show that the Kokap area is dominated by Andesite rocks.

\section{Acknowledgments}

Thanks to the Directorate of Research and Community Service Directorate General of Research and Development of the Ministry of Research, Technology, and Higher Education, who have supported this research financially in contract number: 081 / SP2H / AMD / LT / DRPM / 2020.

\section{References}

Black, P. (2009) Andesites as resources for roading and concrete industries, North Island of New Zealand. Department of Geology. The University of Auckland. 328: 332.

Chalikakis, K., Plagnes, V., Guerin, R., Valois, R., \& Bosch, F. P. (2011). Contribution of geophysical methods to karst-system exploration: an overview. Hydrogeology Journal, 19(6), 1169-1180.

Dentith, M., and Mudge, S. T., (2014) Geophysics for the Mineral Exploration Geoscientist, Cambridge University Press: New York

Department of Transportation. (2015) Strategic Plan of the Director-General of Transportation Year 2015-2019. Jakarta.

Galletti, C. S., Ridder, E., Falconer, S. E., \& Fall, P. L. (2013). Maxent modeling of ancient and modern agricultural terraces in the Troodos foothills, Cyprus. Applied Geography, 39, 4656.

Giamboro WS and Hidayat W. (2016). 3D Modeling of Andesite Rock Resistivity sangon area, Kulonprogo Regency,DIY Province. JIK TekMin, 28(1) 20-26

Government of Kulon Progo Regency. (2007). Kulon Progo District Regulation Number: 16 Year 2007 concerning Long-Term Regional Development Plan Year 2005-2025, Kulon Progo

Guinea, A., Playà, E., Rivero, L., \& Himi, M. (2010). Electrical resistivity tomography and induced polarization techniques applied to the identification of gypsum rocks. Near Surface Geophysics, 8(3), 249-257.

Harjanto, A. (2011). Vulkanostratigraphy In Kulon Jurnal Progo And Around the Region, Special Region of Yogyakarta. MTG ScientificJournal. 4 (8), pp. 1-18

Hersir, G. P., \& Flóvenz, Ó. G. (2013). Resistivity surveying and electromagnetic methods. Global Environment.

Hu, Y., Burucs,Z., vonTucher,S., \&Schmidhalter,U. (2007). Short-termeffects of droughtand salinity on mineral nutrient distribution along growing leaves of maize seedlings. Environmental and Experimental Botany, 60(2), 268-275.

Hrenovic, J., Ivankovic, T., \& Tibljas, D. (2009). The effect of mineral carrier composition on phosphate-accumulating bacteria immobilization. Journal of hazardous materials, 166(2-3), 1377-1382.

Irzon, R. (2018). Comagmatic Andesite and Dacite in Mount Ijo, Kulonprogo: A Geochemistry Perspective. Journal of Geology and mineral resources, 19(4), 221-231.

Jayadi, H., Meidji, I. U., \& Tang, B. Y. (2020). Identifying Andesite Rocks Sources Using Geoelectrical Resistivity in Loli, Donggala Regency, Central Sulawesi. JPSE (Journal of Physical Science and Engineering), 4(2), 45-54. 
Kearey, P., Brooks, M., Hill, I. (2002). An Introduction to Geophysical Exploration, Third Edition. USA. Iowa State University Press

Lugo, E., Playà, E., \& Rivero, L. (2008). Aplicación de la tomografía eléctrica a la prospección de formaciones evaporíticas. Geogaceta, 44, 223-226.

Oh, T. M., Cho, G. C., \& Lee, C. (2014). Effect of soil mineralogy and pore-water chemistry on the electrical resistivity of saturated soils. Journal of Geotechnical and Geoenvironmental Engineering, 140(11), 06014012.

Octova, A., \& Yulhendra, D. (2017). Iron ore deposits model using geoelectrical resistivity method with dipole-dipole array. In MATEC web of conferences, Vol. 101, p. 04017

Phillips, S. J., Anderson, R. P., \& Schapire, R. E. (2006). Maximum entropy modeling of species geographic distributions. Ecological modelling, 190(3-4), 231-259.

Purwasatriya, E. B. (2013). Studi Potensi Sumberdaya Andesit Menggunakan Metode Geolistrik Di Daerah Kokap, Kabupaten Kulonprogo, Daerah Istimewa Yogyakarta. Dinamika Rekayasa, 9(2), 55-61.

Prastowo, R. (2017) Pemodelan 2d Resistivitas Batuan Andesit Daerah Gunung Kukusan Kulon Progo. Kurvatek, 2(2), 87-93.

Prastowo, R., Huda, S., Umam, R., Jemsittiparsert, K., Prasetiyo, A E., Tortop, H S., and Syazali, M. (2019). The Effectiveness Of Environmental Geophysical Learning In Developing Academic Achievement And Conceptual Understanding Of Electrodynamics: Applications Geoelectric Using Cooperative Learning Model; JurnalllmiahPendidikanFisika Al-BiRuNi, $08(2)$

Mackechnie, JR. (2004). Properties of New Zealand concrete aggregates. New Zealand cement and concrete association technical report 11.57pp

Mostafaie, K., \& Ramazi, H. (2015). Application of electrical resistivity method in sodium sulfate deposits exploration, case study: Garmab, Iran. Journal of Biodiversity and Environmental Sciences, 6(2), 2220-6663.

Rahardjo W., Sukandarrumidi dan Rosidi, H.M.D. (1995). Peta Geologi Lembar Yogyakarta, Jawa, Skala 1:100.000, Pusat Penelitian dan Pengembangan Geologi, Bandung

Sadjab, B A., Indrayana, I P T., Iwamony, S., Umam, R. (2020). Investigation of The Distribution and Fe Content of Iron Sand at Wari Ino Beach Tobelo Using Resistivity Method with Werner-Schlumberger Configuration. JurnalIlmiahPendidikanFisika Al-BiRuNi, 09 (1)

Sariisik, A., Sariisik, G., \& Şentürk, A. (2011). Applications of glaze and decor on dimensioned andesites used in construction sector. Construction and Building Materials, 25(9), 36943702.

Telford W., L. Geldart, R. Sheriff dan D. Keys. (1976). Applied Geophysics, 1st Ed. Cambridge, London. New York. Melbourne: Cambridge University Press

Triani, T., Umam, R., Sismanto, S. (2021). 3D Modeling of Subsurface Lawanopo Fault In Southeast Sulawesi, Indonesia Using Grablox and its Consequence to Geohazard. Indonesian Journal of Geography, 53 (1)

Van Bemmelen, RW. (1949) Indonesian Geology Vol. IA, General Geology of Indonesia and Adjacent Islands. Government Printing Office. Hague. 598

Woodruff, L., Cannon, W. F., Smith, D. B., \& Solano, F. (2015). The distribution of selected elements and minerals in soil of the conterminous United States. Journal of Geochemical 
Exploration, 154, 49-60.

Yan, J. Y., Meng, G. X., LV, Q. T., Zhang, K., \& Chen, X. B. (2012). The progress and prospect of the electrical resistivity imaging survey. Geophysical and Geochemical Exploration, 4 